\section{Influence of Rootstock and Irrigation Methods on Water Use, Mineral Nutrition, Growth, Fruit Yield, and Quality in 'Gala' Apple}

\author{
Esmaeil Fallahi ${ }^{1}$
}

ADDITIONAL INDEX WORDs. evapotranspiration, $\mathrm{ET}_{\mathrm{c}}$, high-density orchards, Malus domestica, mineral nutrition, water use efficiency

SUMMARY. The increasing trend in the world population and decreasing trend in the suitable land for fruit production, combined with a shortage of water, mandate the use of efficient methods of irrigation and establishment of high-density orchards that require size-controlling rootstocks. Method of irrigation and vigor of rootstock are among the most important factors affecting uptake of mineral nutrients, and thus tree growth and fruit yield and quality attributes of apple (Malus domestica). In a long-term experiment, effects of two irrigation methods and four rootstocks on water use, tree growth, fruit quality, and leaf mineral nutrients were studied in 'Pacific Gala' apple. The experiment was conducted in southwestern Idaho, which represents the high desert conditions of the Intermountain West region of the United States. Evapotranspiration-based irrigation scheduling $\left(E T_{c}\right)$, adjusted by percentage of ground shading, was used for sprinkler and drip systems. Significantly lower volume of water was applied to the trees with drip irrigation than those with sprinkler irrigation system. Leaf calcium (Ca) decreased but leaf potassium $(\mathrm{K})$ increased with rootstock vigor, resulting in the greatest leaf $\mathrm{Ca}$ but lowest leaf $\mathrm{K}$ in trees on 'Budagovsky 9' (B.9). Fruit weight and yield per tree in 'Pacific Gala' on 'Nic 29' (RN29) rootstock was higher than those on B.9 and 'Geneva 30' (G.30) rootstocks. 'Pacific Gala' on B.9 rootstock had smaller trees and fruit size but higher fruit starch degradation pattern (SDP), suggesting earlier fruit maturity on this rootstock. On average, 'Pacific Gala' trees with drip irrigation had larger fruit and higher leaf magnesium $(\mathrm{Mg})$ and manganese $(\mathrm{Mn})$ but less fruit color and firmness and lower leaf $\mathrm{Ca}, \mathrm{K}$, zinc $(\mathrm{Zn})$, and copper $(\mathrm{Cu})$ than those with sprinkler system.

$\mathrm{T}$ he constant increase in world population and decrease in irrigation water availability mandate a more efficient use of water in agriculture. Merging new orchard designs with more efficient irrigation systems and rootstocks can result in lower water consumption (Fallahi et al., 2007a; Neilsen et al., 2006, 2008) while producing higher quality fruit (Autio et al., 1996; Behboudian and

Professor and Director of Pomology Program, University of Idaho, Parma Research and Extension Center, 29603 U of I Lane, Parma, ID 83660

This paper was part of the workshop "Nutrient and Water Management Practices for Improving Crop Growth, Yield, and Quality" held on 26 Sept. 2011 at the ASHS Conference, Waikoloa, HI, and sponsored by the Plant Nutrient Management (PNM) Working Group.

The authors thank the Idaho Apple Commission and International Fruit Tree Association, and the Idaho Agricultural Experiment Station for their financial support of this project.

The authors are also thankful to the Columbia Basin, Van Well, and C \& O Nurseries in Washington State for providing the experimental trees and to $\mathrm{Mr}$. Richard L. Bronson, Pipeco, Fruitland, ID, for his invaluable contribution and assistance in designing the irrigation layout and providing the irrigation materials for this project.

${ }^{1}$ Corresponding author. E-mail: efallahi@uidaho.edu.
Mills, 1997; Behboudian et al., 2005; Fallahi et al., 2007a, 2007b; Naor et al., 2008; Neilsen et al., 2010).

Rootstock can influence ripening, color, and shape of the scion fruit. Autio et al. (1996) in the 1984 NC-140 cooperative planting reported that apple fruit ripening was correlated with tree vigor and the most dwarfing rootstocks resulted in the earliest ripening. Rootstock can also influence scion leaf and fruit mineral concentrations and indirectly affect fruit quality and yield (Fallahi et al., 200la, 2001b).

Leib et al. (2006) indicated that fruit size and yield of 'Fuji' apple in deficit irrigation (DI) were similar to those of partial root zone drying irrigation and conventional irrigation (CI) in the semiarid climate of Washington State. Naor et al. (2008) reported that yield and fruit size decreased as the rate of irrigation was reduced in 'Golden Delicious' apple in Israel. Previous reports have indicated that a reduction in water application may result in a reduction in apple firmness, relating this observation to the advanced maturity in fruit with water stress (Drake et al., 1981; Mills et al., 1994). However, other studies have shown that apples from nonirrigated plots were firmer than those from irrigated plots because fruit from nontreated plots had smaller size (Assaf et al., 1975).

Irrigation with a drip system uses lower water volume than sprinkler irrigation (Fallahi et al., 2007a; Proebsting, 1994). However, irrigation through microjet sprinkler systems can improve the establishment and maintenance of orchard floor vegetation. Microjet sprinklers also create a cooler environment in the orchards under the fruit-growing conditions of Washington and Idaho (E. Fallahi, personal observation). Although there has been some progress in the understanding of microirrigation systems (Chun et al., 2001; Fallahi et al., 2007a; Neilsen et al., 1994, 2010; Yao et al., 2001; Zydlik and Pacholak, 2001), information on tree growth, yield, and fruit quality for new apple cultivars under various regimes of

\begin{tabular}{llll}
\hline $\begin{array}{l}\text { Units } \\
\text { To convert U.S. to SI, } \\
\text { multiply by }\end{array}$ & U.S. unit & SI unit & $\begin{array}{l}\text { To convert SI to U.S., } \\
\text { multiply by }\end{array}$ \\
\hline 0.4047 & acre $(\mathrm{s})$ & $\mathrm{ha}$ & 2.4711 \\
0.3048 & $\mathrm{ft}$ & $\mathrm{m}$ & 3.2808 \\
3.7854 & gal & $\mathrm{L}$ & 0.2642 \\
2.54 & inch $(\mathrm{es})$ & $\mathrm{cm}$ & 0.3937 \\
25.4 & inch(es) & $\mathrm{mm}$ & 0.0394 \\
6.4516 & inch ${ }^{2}$ & $\mathrm{~cm}^{2}$ & 0.1550 \\
0.4536 & $\mathrm{lb}$ & $\mathrm{kg}$ & 2.2046 \\
1.1209 & $\mathrm{lb} / \mathrm{acre}^{2}$ & $\mathrm{~kg} \cdot \mathrm{ha}^{-1}$ & 0.8922 \\
0.0703 & $\mathrm{lb} / \mathrm{inch}^{2}$ & $\mathrm{~kg} \cdot \mathrm{cm}^{-2}$ & 14.2233 \\
28.3495 & $\mathrm{oz}$ & $\mathrm{g}$ & 0.0353 \\
28,350 & $\mathrm{oz}$ & $\mathrm{mg}$ & $3.5274 \times 10^{-5}$ \\
$4.3942 \times 10^{3}$ & $\mathrm{oz} / \mathrm{inch}^{2}$ & $\mathrm{mg} \cdot \mathrm{cm}^{-2}$ & $2.2757 \times 10^{-4}$ \\
1 & $\mathrm{ppm}$ & $\mu \mathrm{gg} \cdot \mathrm{g}^{-1}$ & 1 \\
6.8948 & $\mathrm{psi}$ & $\mathrm{kPa}$ & 0.1450 \\
$\left({ }^{\circ} \mathrm{F}-32\right) \div 1.8$ & ${ }^{\circ} \mathrm{F}$ & ${ }^{\circ} \mathrm{C}$ & $\left({ }^{\circ} \mathrm{C} \times 1.8\right)+32$ \\
& & & \\
\hline
\end{tabular}


Table 1. Precipitation, evapotranspiration (ET), depth of applied water, and total volume of applied water per tree in 'Pacific Gala' apple from 2004 to 2007.

\begin{tabular}{lcccrrr}
\hline Precipitation, ET, or applied water $^{\mathbf{z}}$ & $\mathbf{2 0 0 4}$ & $\mathbf{2 0 0 5}$ & Avg 2004-05 & 2006 & 2007 & Avg 2006-07 \\
\hline Precipitation (inches) & 2.55 & 2.65 & 2.60 & 2.14 & 2.20 & 2.17 \\
ET $_{\mathrm{r}}$ (inches) & 36.44 & 37.64 & 37.04 & 42.04 & 45.09 & 43.57 \\
ET $_{\mathrm{c}}$ (inches) & 33.32 & 36.64 & 34.98 & 40.27 & 42.43 & 41.35 \\
Water applied by sprinkler (inches) & 33.32 & 35.36 & 34.34 & 37.84 & 40.42 & 39.13 \\
Water applied by drip (inches) & 14.54 & 20.80 & 17.67 & 23.41 & 24.94 & 24.18 \\
Applied by sprinkler (gal/tree) & 1426.6 & 1541.3 & 1484 & 1651.2 & 1763.1 & 1707.2 \\
Applied by drip (gal/tree) & 635.2 & 908.3 & 771.8 & 1023.0 & 1088.8 & 1055.9 \\
\hline
\end{tabular}

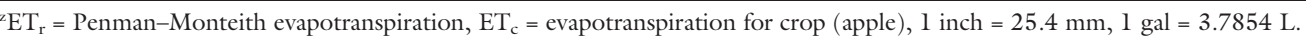

drip or microjet sprinkler irrigation systems in the Pacific northwestern United States is lacking. Thus, the objective of this long-term experiment was to study the effect of four rootstocks and two irrigation treatments consisting of microjet sprinkler and drip systems, using $\mathrm{ET}_{\mathrm{c}}$-based water scheduling, on water use, tree growth, yield, and harvest-time fruit quality attributes during 2004-07 and leaf mineral nutrients during 2002-07 in 'Pacific Gala' apple.

\section{Materials and methods}

Orchard establishment. The experimental orchard was established at the University of Idaho Parma Research and Extension Center in the spring and early summer of 2002. 'Pacific Gala' trees on four rootstocks (B.9, RN29, G.30, and 'Supporter4') were planted at $5 \times 14$ - $\mathrm{ft}$ spacing with an east-west row orientation. This group of rootstock was selected to create a range of tree sizes from dwarf to vigorous. 'Manchurian' crabapple (Malus baccata) on RN29 rootstock (C\&O Nursery, Wenatchee, WA) was planted in each row as a pollinizer between every 10 'Pacific Gala' trees. The experimental site had a semiarid climate, with an annual precipitation of $\approx 11.1$ inches and a sandy loam soil of $\mathrm{pH}$ of $\approx 7.3$. Crested wheatgrass (Agropyron cristatum), which is a drought tolerant grass, was planted as the orchard floor cover in all treatments.

Trees were trained into a vertical axis system during the dormant season in early March every year. Tree leaders were maintained at $\approx 12$ - $\mathrm{ft}$ height. Trees in all treatments were blossom thinned at $\approx 85 \%$ bloom with $5 \%$ lime sulfur, followed by one or two applications of postbloom thinners. The first postbloom thinner was a mixture of carbaryl (44.1\% a.i. by weight, Sevin XLR; Bayer Crop
Science, Research Triangle Park, NC) at a rate of 1 to $1.5 \mathrm{lb} /$ acre a.i. and ethephon (21.7\% a.i., Ethrel, Bayer Crop Science) at a rate of 454 to 681 $\mathrm{g} /$ acre a.i., and was applied at petal fall. The second postbloom thinner (when applied, depending on the crop load) was carbaryl (Sevin XLR) at a rate of $1 \mathrm{lb} /$ acre a.i. that was applied when fruitlet diameter was $\approx 7 \mathrm{~mm}$. Fruit were subsequently hand thinned when average fruit size was $\approx 18-\mathrm{mm}$ diameter (around mid-June) to maintain a space of at least 5 to 6 inches between fruit. Kaolin (95\% a.i., Surround; Engelhard, Iselin, NJ) was sprayed for sunburn protection at the rate of $47.5 \mathrm{lb} /$ acre a.i. in early July, followed by three 1-week-interval applications, each at $23.8 \mathrm{lb} /$ acre a.i. every year.

Weeds were controlled chemically to maintain a 5-ft-wide weed-free herbicide strip under trees. Cultural practices other than irrigation were similar to those recommended for commercial orchards in the Pacific northwestern United States (Washington State University, 2012).

IRRIGATION REgIMES. There were two irrigation methods in this study: full sprinkler (FS) and full drip (FD). Each irrigation regime was applied in one row, consisting of four rootstocks as described earlier. A row of guard trees was used between every two experimental rows. These trees received only drip irrigation to prevent any possible overspray from the sprinkler systems in the experimental rows. Trees from the guard rows were not used in the study.

The two irrigation regimes (FS and FD) in this study were as follows: 1) (FS) $30-\mathrm{cm}$ microjet sprinklers (Olson Ultra-jet, Santee, CA) were connected to a lateral polyethylene line installed in a 6-inch-deep trench (subsurface), $1 \mathrm{ft}$ away from and parallel to the tree row. Each microjet sprinkler was installed midway between two adjacent trees and covered a complete circle with a radius of $7 \mathrm{ft}$. In this treatment, trees were irrigated once per week at the full rate of $\mathrm{ET}_{\mathrm{c}}$ for apple starting in 2002 (see "calculation for water application" below).

2) (FD) One 16-mm drip line (Rain Bird Corp., Azusa, CA) was installed in a 4-inch-deep trench (subsurface), $1 \mathrm{ft}$ away from and parallel to the tree row on each of the north and south sides of the tree row. Each of these lines was connected to a pressure regulator to keep the water pressure constant at 20 psi. Pressure compensating emitters were spaced at 18 inches on each line, and each emitter delivered $0.62 \mathrm{gal} / \mathrm{h}$ of water. Pressure compensation ensured consistent flow from each inline emitter throughout the entire length of tubing and the emitter design prevented debris from clogging emitters for maximum performance. The drip line on the north side of the tree was "off-centered" with the line in the south side to provide better water coverage. Trees in this system were irrigated twice per week at $100 \%$ of daily $\mathrm{ET}_{\mathrm{c}}$ (as described below), but adjusted for the ground shading area (GS). Therefore, in this treatment, gallons of water applied per tree $=0.623 \times\left(\mathrm{ET}_{\mathrm{c}}\right.$ in inches $/$ percent drip efficiency factor $) \times 5 \times 14$ $\mathrm{ft}$ spacing $\times$ percent GS. In this formula, GS was estimated as the area of orchard shaded by the tree canopy at different stages of growth.

Irrigation treatments were initiated in about mid-May and ended in mid-October every year. Shortly before the first irrigation of the year, soil moisture was measured using sensors (AquaPro Sensors, Decor, CA), and trees were watered to the soil saturation point. After this general irrigation, water requirements were calculated 
based on $\mathrm{ET}_{\mathrm{c}}$ where $\mathrm{ET}_{\mathrm{c}}=\mathrm{ET}_{\mathrm{r}} \times K_{\mathrm{c}}$ with $\mathrm{ET}_{\mathrm{r}}$ [Penman-Monteith reference ET (Allen et al., 1998)] being calculated from the Agri-Met Parma Weather Station data and $K_{\mathrm{c}}$ being the crop coefficient. Each year, starting from 2002, the crop water use coefficient was calculated as $K_{\mathrm{c}}=K_{\mathrm{c}}$ base $+\% \mathrm{M} \times\left(\right.$ mature $K_{\mathrm{c}}-K_{\mathrm{c}}$ base $)$. Percent canopy maturity $(\% M)$ was a measurement of tree canopy size and was calculated as $\% \mathrm{M}=3.05+2.558 \times$ (percent GS) $-0.016 \times(\text { percent GS })^{2}$. $K_{\mathrm{c}}$ base was the base coefficient, calculated as the percentage area between the rows that was occupied by a cover crop. In this experiment, spacing between rows was $14 \mathrm{ft}$ and the herbicide strip extended $2 \mathrm{ft}$ on either side of the row. Thus, $K_{\mathrm{c}}$ base was $[14-(2 \times 2) /$ $14=0.71]$. In early 2005 , GS reached $62 \%$, and tree maturity reached $100 \%$ in early Aug. 2005; thus, $K_{c}$ values for mature trees were used after 1 Aug. 2005. Since crested wheatgrass was planted as the orchard floor cover plant, value for mature $K_{\mathrm{c}}$ for each month was adopted from Proebsting (1994) for apple with cover crop (i.e., 0.71 in May, 0.96 in June, 1.04 in July and August, 1.00 in September, and 0.79 in October).

Several random checks were made to test the accuracy of water delivery in both irrigation systems every year. Based on the precision in designing the irrigation systems and these random checks, an efficiency factor of $100 \%$ was assumed for all irrigation treatments. Rainfall during the growing seasons was low and when it rained, this amount was subtracted from the $\mathrm{ET}_{\mathrm{c}}$ value to calculate the actual amount of irrigation needed in each application.

TREe GROWTH, YIELD, LEAF SIZE AND MINERALS, AND FRUIT QUALITY ATTRIBUTES. For monitoring tree growth, trunk cross-sectional area (TCA) was calculated by measuring trunk diameter at $\approx 20 \mathrm{~cm}$ above the bud union $(\approx 12 \mathrm{~cm}$ above the soil line) in early March every year. For this purpose, two measurements were made, one from the east-west and the other one from the north-south directions and the diameter values were averaged and the radius was computed. Tree TCA was calculated every year from 2004 through 2007. Yield per tree was recorded at harvest time and yield efficiency was calculated as total yield per tree in kilograms per square centimeter of TCA. Three individuals independently estimated fruit sunburn just before harvest, as percentage of fruit with visible sunburn symptoms on each tree, and the three values were averaged.

Leaf area and mineral concentrations were measured annually. For measurements of leaf area, leaf size, and mineral nutrients, 30 leaves per tree were sampled randomly from the middle of the current-season's shoot in mid-August each year. Leaf area was measured using a leaf area meter (model LI-3100; LI-COR, Lincoln, $\mathrm{NE}$ ). Leaves were washed in a mild Liqui-nox detergent (Alconox, White Plains, NY) solution, rinsed with distilled water, and dried in a forced-air oven at $65^{\circ} \mathrm{C}$. Leaves were weighed before and after drying, and percent dry weight was calculated. Dried leaves were ground to pass a 40-mesh screen using a Cyclotec Sample Mill (model 1093; Tecator, Hoganas, Sweden). Nitrogen $(\mathrm{N})$ concentration was determined by combusting dry tissues using a protein/N analyzer (model FP-528; LECO Corp., St. Joseph, MI). Leaf tissues were analyzed for $\mathrm{K}, \mathrm{Ca}, \mathrm{Mg}$, iron, $\mathrm{Zn}, \mathrm{Mn}$, and $\mathrm{Cu}$ by dry ashing at $500{ }^{\circ} \mathrm{C}$, digestion, and atomic absorption spectrophotometry (model B1100; Perkin-Elmer, Norwalk, CT) as generally described by Chaplin and Dixon (1974).

Twenty fruit were randomly sampled from each tree between 10 and 25 Aug. in 2004-07. For quality evaluation at harvest, fruit were gently wiped with a damp cloth and percentage of fruit with visible russet was recorded. Fruit were weighed and skin color was visually ranked on a scale of 1 to 5 , with $1=20 \%$ red and $5=100 \%$ red. Soluble solids concentration (SSC) was measured using a temperaturecompensated refractometer (N1; Atago, Tokyo, Japan) and fruit firmness was measured using an 11-mm probe, with a fruit texture analyzer (Guss Manufacturing, Strand, South Africa). Fruit were cut equatorially in half and the number of fruit with visible water core symptoms was recorded. The percentage of water core was calculated as the percentage of water-cored fruit in the total number of fruit evaluated for quality. SDP of equatorial slices of each fruit was recorded by comparison with the SDP standard chart developed for 'Gala' apples by Bartram et al. (1993).

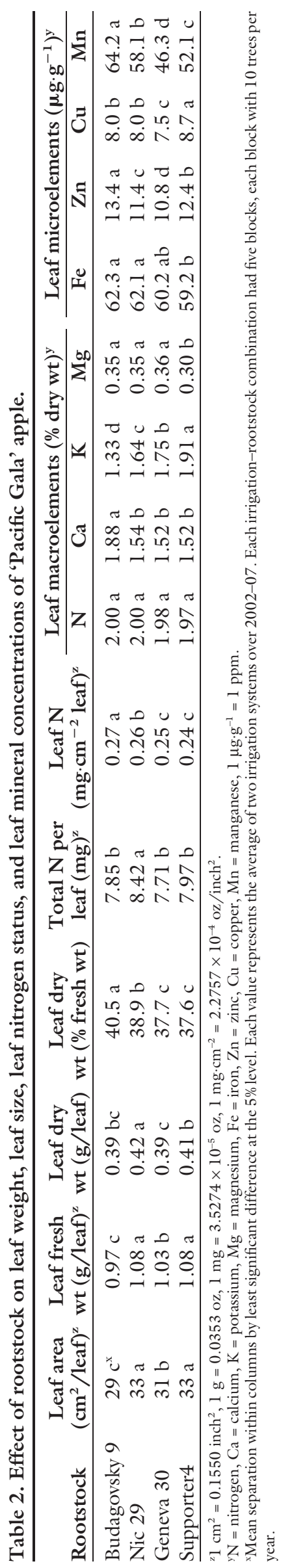


Table 3. Effect of rootstock on tree growth, yield, and fruit quality attributes at harvest in 'Pacific Gala' apple.

\begin{tabular}{|c|c|c|c|c|c|c|c|c|}
\hline \multirow[b]{2}{*}{$\underline{\text { Rootstock }}$} & \multirow[b]{2}{*}{$\begin{array}{c}2006 \\
\operatorname{TCA}\left(\mathrm{cm}^{2}\right)^{\mathrm{z}}\end{array}$} & \multicolumn{2}{|c|}{ 2006-07 Cumulative } & \multicolumn{5}{|c|}{ Fruit quality attributes at harvest } \\
\hline & & $\begin{array}{c}\text { Yield } \\
(\mathrm{kg} / \text { tree })^{\mathrm{y}}\end{array}$ & $\begin{array}{c}\text { Yield } \\
\text { efficiency } \\
\left(\mathrm{kg} \cdot \mathrm{cm}^{-2} \mathrm{TCA}\right)^{\mathrm{y}}\end{array}$ & $\begin{array}{c}\text { Fruit } \\
\text { wt }(g)^{y}\end{array}$ & $\begin{array}{c}\text { Color } \\
(1-5 \text { scale })^{x}\end{array}$ & $\begin{array}{c}\text { Firmness } \\
(\mathrm{kg})^{\mathrm{y}}\end{array}$ & $\begin{array}{c}\text { Soluble } \\
\text { solids (\%) }\end{array}$ & $\begin{array}{c}\text { Starch } \\
\text { degradation } \\
\text { pattern }(1-6 \text { scale })^{w}\end{array}$ \\
\hline Budagovsky 9 & $14.4 \mathrm{c}^{\mathrm{v}}$ & $64.0 \mathrm{~b}$ & $1.25 \mathrm{a}$ & $193.2 \mathrm{c}$ & $3.5 \mathrm{ab}$ & $8.33 \mathrm{bc}$ & $14.3 \mathrm{a}$ & $4.39 \mathrm{a}$ \\
\hline Nic 29 & $31.3 \mathrm{~b}$ & $93.1 \mathrm{a}$ & $0.86 \mathrm{~b}$ & $214.5 \mathrm{a}$ & $3.4 \mathrm{ab}$ & $8.50 \mathrm{~b}$ & $13.9 \mathrm{bc}$ & $3.80 \mathrm{~b}$ \\
\hline Geneva 30 & $33.2 \mathrm{~b}$ & $75.4 \mathrm{~b}$ & $0.67 \mathrm{c}$ & $200.8 \mathrm{~b}$ & $3.6 \mathrm{a}$ & $8.18 \mathrm{c}$ & $14.1 \mathrm{ab}$ & $4.29 \mathrm{a}$ \\
\hline
\end{tabular}

${ }^{2} \mathrm{TCA}=$ trunk cross-sectional area, $1 \mathrm{~cm}^{2}=0.1550$ inch $^{2}$.

${ }^{\mathrm{y}} \mathrm{l} \mathrm{kg}=2.2046 \mathrm{lb}, \mathrm{l} \mathrm{kg} \cdot \mathrm{cm}^{-2}=14.2233 \mathrm{lb} /$ inch $^{2}, 1 \mathrm{~g}=0.0353 \mathrm{oz}$.

${ }^{\mathrm{x}} \mathrm{l}=$ green skin color, 5 = red skin color.

${ }^{\mathrm{w}}$ Comparison vs. the standard chart developed for 'Gala' apples by Bartram et al. (1993).

${ }^{v}$ Mean separation within columns by least significant difference at $5 \%$ level. Each value represents the average of two irrigation systems over $2004-07$, each with five 10 -tree blocks per year.

EXPERIMENTAL DESIgNS AND statistics. The experimental design was a randomized complete block split plot with two irrigation treatments as main plots and four rootstocks as subplots and five blocks (replicates). Each block contained 10 trees per plot of each irrigation treatment, five of which in the center of the plot were used for measurements (i.e., a total of 50 trees per treatment, of which 25 trees were used for measurements). Data were collected between 2002 and 2007 for leaf mineral nutrients and between 2004 and 2007 for tree growth, yield, and quality attributes. The assumption of normal data distribution was checked by computing univariate analyses for all tree responses in this study. Analyses of variance were conducted by using SAS (version 9.3; SAS Institute, Cary, NC), with PROC GLM and means were compared by least significant difference at $P \leq 0.05$.

\section{Results and discussion}

InTERACTION. There was no interaction between year and irrigation methods or rootstock treatments for any of the amount of applied water, tree growth, yield, and fruit quality attributes. Thus, average values overall years from 2002 through 2007 for leaf size and mineral nutrients and 2004-07 for yield and fruit quality attributes are reported here.

WATER APPLICATION. The average precipitation during the irrigation periods of 2004-05, when trees were not yet fully mature, was 2.6 inches (Table 1), and the average for 200607 irrigation periods, when trees were mature, was 2.17 inches (Table 1 ). During the irrigation period in all years, July had the lowest precipitation. Water application in all irrigation regimes increased as trees matured
(Table 1). As expected, trees used the highest water volume in July and August in all years. Trees with a FS system received $72 \%$ and $56 \%$ higher water volume than those with a FD system in 2003 (data not shown) and 2004 (Table 1), respectively. The differences between water applications in FS and FD systems were consistent (38\% to $41 \%$ ) after 2005 (Table 1) because trees had reached the maximum ground shading $(\approx 62 \%)$ and full canopy maturity after 1 Aug. 2005. On average, mature trees with a FS system received 1707.2 gal of water per tree (39.13 inches), while those with a FD system received $1055.9 \mathrm{gal}$ of water per tree $(24.18$ inches) over the 2006 and 2007 seasons (Table 1). Leib et al. (2006) compared three microsprinkler irrigation systems in mature 'Fuji' trees in Washington State. In that study, the soil water content in the CI was maintained close to field capacity, which was only $60 \%$ to $70 \%$ of estimated $\mathrm{ET}_{\mathrm{c}}$ for apple without cover crop. That study estimated that irrigation scheduling based on soil-water measurements required $26 \%$ lower water than what was predicted by the $\mathrm{ET}_{\mathrm{c}}$ model for an apple orchard without a cover crop. That study also showed that the three-year average potential ET $\left(\mathrm{ET}_{\mathrm{o}}\right)$ was 39 inches, $\mathrm{ET}_{\mathrm{c}}$ was $\approx 31.1$ inches, and irrigation amounts applied were 27.83 inches for CI irrigation regimes. In this study, when trees were mature (2006 and 2007), the two-year average for $\mathrm{ET}_{\mathrm{r}}$ was 43.57 and for $\mathrm{ET}_{\mathrm{c}}$ was 41.35 inches (Table 1); thus, these values were $\approx 11 \%$ and $25 \%$ higher than similar measurements in Washington, respectively. During 2006 and 2007, we applied an average of 39.13 inches of water to the FS trees, which was $\approx 11.3$ inches $(\approx 29 \%)$ higher than the levels applied to the CI treatment in the report from Washington State (Leib et al., 2006). This difference was due to the higher $\mathrm{ET}_{\mathrm{r}}$ and $\mathrm{ET}_{\mathrm{c}}$ values in Idaho than Washington. In addition, the trees with $\mathrm{FS}$ received full $\mathrm{ET}_{\mathrm{c}}$ level in the study (Table 1), while CI trees in Leib et al. (2006) received water at $70 \%$ of $\mathrm{ET}_{\mathrm{c}}$. Rainfall in both experiments was comparable.

EFFECTS OF ROOTSTOCK ON LEAF SIZE AND MINERAL NUTRIENTS. Leaves from trees on $\mathrm{G} .30$ rootstock had the highest leaf area and fresh weight but lower percent dry weight than those on all other rootstocks. The exact opposite situation existed for trees on B.9 rootstock. Thus, leaves from trees on B.9 rootstock had the smallest leaf area and fresh weight but higher percent dry weight than those on all other rootstocks (Table 2 ).

There were no significant differences in leaf $\mathrm{N}$ concentrations among rootstocks when $\mathrm{N}$ was expressed on dry weight bases (Table 2). However, leaf $\mathrm{N}$ per square centimeter leaf area decreased with rootstock vigor so that B.9 had the highest value and those on 'Supporter4' had the lowest value (Table 2). Trees on RN29 had higher total $\mathrm{N}$ per leaf (Table 2). Therefore, expression of leaf minerals on a unit of leaf area might provide an improved diagnostic tool than that on a dry weight basis.

Trees on B.9 had higher concentrations of leaf $\mathrm{Ca}, \mathrm{Zn}$, and $\mathrm{Mn}$, but lower concentration of $\mathrm{K}$ when compared with those on other rootstocks. Trees on 'Supporter4' had higher leaf $\mathrm{K}$ and $\mathrm{Cu}$ than those on other rootstocks.

In general, leaf $\mathrm{K}$ and $\mathrm{Mg}$ had antagonistic while leaf $\mathrm{N}$ and $\mathrm{Mn}$ had synergistic effect to each other (Table 2). 
EFFECTS OF ROOTSTOCK ON TREE GROWTH AND YIELD. 'Gala' trees on B.9 had significantly smaller TCA while those on 'Supporter4' had larger TCA than those on other rootstocks (Table 3). Trees on RN29 had smaller TCA than those on G.30 when trees were young in 2004 and 2005 (data not shown), but the tree size differences became insignificant when trees were mature, resulting in similar TCA in 2006 (Table 3). Judging based on the foliage density after tree canopy reached $100 \%$ maturity ( $\approx 67 \% \mathrm{GS}$ ), 5 - $\mathrm{ft}$ spacing between trees was too far for trees on B.9 and could have been planted as close as 3- to 4 - $\mathrm{ft}$ spacing. Even between-row spacing for this rootstock could have been reduced from $14 \mathrm{ft}$ to $12-13 \mathrm{ft}$; thus, tree density on B.9 could have been increased from its current density of 622 trees/acre to 838-1210 trees/ acre. However, 5 -ft spacing between trees was appropriate for trees on RN29 rootstock. In contrast, 'Supporter4' was too vigorous for planting under the tree spacing of this study.

Trees on RN29 had a higher cumulative yield over the 2004-07 seasons. Trees on B.9 and RN29 were more precocious and had higher yield per tree and yield efficiency than those on 'Supporter4' in 2004 and 2005 [two and three years after planting, respectively (data not shown)]. Thus, both of these rootstocks can be recommended for their yield under closed-space conditions of this study. 'Supporter4' was not a suitable rootstock for 'Pacific Gala' in this study as trees were too vigorous and had low yield efficiency.

EFFECTS OF ROOTSTOCK ON FRUIT QUALITY ATTRIBUTES. Trees on RN29 often had higher fruit weight, but trees on B.9 had lower fruit weight than did those on other rootstocks (Table 3). Smaller fruit in trees on B.9 were due to a lower leaf:fruit ratio and smaller leaf size. Fruit in trees on all rootstocks were kept at $\approx 15$-cm spacing at the time of thinning, leading to a lower leaf:fruit ratio in B.9 rootstock because these rootstock had smaller TCA (Table 3) and lower foliage density (data not shown). Usually, lower yield is associated with larger fruit size. However, trees on 'Supporter4' had smaller fruit in spite of lower yield and were not suitable for planting.
Rootstock did not have a major and consistent impact on the 'Gala' fruit color. Trees on 'Supporter4' had slightly less red color than those on other rootstocks, which could be due to the larger canopy size and higher shading on the trees.

Fruit from 'Pacific Gala' trees on B.9 and G.30 had higher SSC and SDP and had lower firmness than those on other rootstocks (Table 3 ). This observation suggests that both B.9 and G.30 rootstocks advance fruit maturity in 'Pacific Gala'. Fruit from trees on 'Supporter4' had significantly higher firmness at harvest than those on other rootstocks because of its smaller fruit size (Table 3 ).

EFFECTS OF IRRIGATION ON LEAF MINERAL NUTRIENTS, TREE GROWTH, AND FRUIT YIELD AND QUALITY. On average, leaves from 'Pacific Gala' trees with FD irrigation system had higher fresh weight, dry weight, percent dry weight, total $\mathrm{N}$ per leaf, milligrams of $\mathrm{N}$ per square centimeter of leaf, $\mathrm{Mg}$, and $\mathrm{Mn}$; but had lower leaf $\mathrm{Ca}, \mathrm{K}, \mathrm{Zn}$, and $\mathrm{Cu}$ (Table 4) and lower fruit color (Table 5) than did those with FS system. The lower color of fruit from trees with FD system was due to higher total $\mathrm{N}$ per leaf and milligrams of $\mathrm{N}$ per square centimeter of leaf (Table 4).

Trees with FD system were more precocious and had larger fruit, higher yield per tree, and yield efficiency than trees with FS system in 2003 (data not shown), but there was no difference in cumulative yield over 2004-07 between trees with FS and FD systems (Table 5 ). There was no consistent effect of irrigation system on fruit SSC. However, fruit from trees with FD system often had higher SDP and lower firmness than those from FS irrigation (Table 5), suggesting that fruit with FD were slightly more mature because of water stress than those with FS system. Nevertheless, this advanced maturity did not cause a major difference in fruit stemend cracking between the two irrigation treatments (data not shown).

Leib et al. (2006) showed that SSC in fruit from trees receiving DI was higher than in fruit from trees receiving CI. A two-year study by $\mathrm{O}^{\prime}$ Connell and Goodwin (2007) on 'Pink Lady' in Victoria, Australia, showed that SSC tended to be higher in DI fruit than CI fruit for each of the two years. In contrast, Talluto et al.

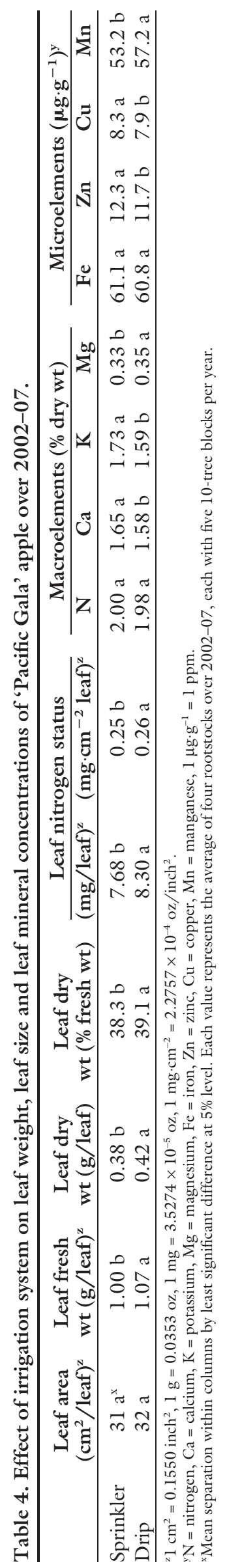


Table 5. Effect of irrigation system on yield and fruit quality attributes of 'Pacific Gala' apple over $2004-07$.

\begin{tabular}{|c|c|c|c|c|c|c|c|}
\hline \multirow[b]{2}{*}{ Irrigation } & \multirow[b]{2}{*}{$\begin{array}{c}2006 \text { TCA } \\
\left(\mathrm{cm}^{2}\right)^{\mathrm{z}}\end{array}$} & \multicolumn{2}{|c|}{ Cumulative } & \multicolumn{4}{|c|}{ Fruit quality attributes at harvest } \\
\hline & & $\begin{array}{c}\text { Yield } \\
(\mathrm{kg} / \text { tree })^{\mathrm{y}}\end{array}$ & $\begin{array}{c}\text { Yield efficiency } \\
\left(\mathrm{kg} \cdot \mathrm{cm}^{-2} \text { TCA }\right)^{\mathrm{y}}\end{array}$ & $\begin{array}{l}\text { Fruit wt } \\
(\mathrm{g})^{\mathrm{y}}\end{array}$ & $\begin{array}{c}\text { Color } \\
(1-5 \text { scale })^{x}\end{array}$ & $\begin{array}{c}\text { Firmness } \\
(\mathrm{kg})^{\mathrm{y}}\end{array}$ & $\begin{array}{c}\text { Soluble } \\
\text { solids (\%) }\end{array}$ \\
\hline Sprinkler & $31.27 \mathrm{a}^{\mathrm{w}}$ & $64.2 \mathrm{a}$ & $0.72 \mathrm{a}$ & $198.5 \mathrm{~b}$ & $3.69 \mathrm{a}$ & $8.55 \mathrm{a}$ & $14.0 \mathrm{a}$ \\
\hline Drip & $27.73 \mathrm{~b}$ & $66.2 \mathrm{a}$ & $0.77 \mathrm{a}$ & $205.7 \mathrm{a}$ & $3.27 \mathrm{~b}$ & $8.32 \mathrm{~b}$ & $14.0 \mathrm{a}$ \\
\hline
\end{tabular}

${ }^{\mathrm{z}} \mathrm{TCA}=$ trunk cross-sectional area, $1 \mathrm{~cm}^{2}=0.1550 \mathrm{inch}^{2}$.

$\mathrm{y}=2.2046 \mathrm{lb}, 1 \mathrm{~kg} \cdot \mathrm{cm}^{-2}=14.2233 \mathrm{lb} /$ inch $^{2}, 1 \mathrm{~g}=0.0353 \mathrm{oz}$.

${ }^{\mathrm{x}} \mathrm{l}=$ green skin color, $5=$ red skin color.

wean separation within columns by least significant difference at $5 \%$ level. Each value represents the average of two irrigation systems over $2004-07$, each with five 10 -tree blocks per year.

(2008) reported that 'Pink Lady' fruit from DI and CI treatments had similar SSC. Differences in the volume of water applied in DI treatments and method of calculation for water requirement $\left(\mathrm{ET}_{\mathrm{c}}\right.$ vs. soil moisture content) could partially explain these contradictory reports.

Based on this long-term study, an ET-based irrigation scheduling, adjusted by GS and $K_{\mathrm{c}}$ factors, can be successfully used to produce highquality 'Gala' apple under climatic conditions of this study. Since trees with a FD system received less water (Table 1 ) and were more precocious with significantly higher yield per tree than those with a FS system during early years of planting, we suggest that FD is a preferred method of irrigation over a FS system for 'Gala' apple.

\section{Conclusions}

A significantly greater volume of water was required for trees under full microjet sprinkler systems than those with drip systems. However, application of water through a drip system, based on full $\mathrm{ET}_{\mathrm{c}}$ rate and adjusted by percentage of ground shade, can result in greater water savings and improves apple yield and fruit quality. Considering growth, yield, and fruit quality attributes in this study, a wellcalculated $\mathrm{ET}_{\mathrm{c}}$-based $\mathrm{FD}$ irrigation method could be recommended over a sprinkler irrigation regime for modern high-density apple orchards. B.9 and RN29 were excellent rootstocks for 'Pacific Gala' apple in this type of production system.

\section{Literature cited}

Allen, R.G., L.S. Pereira, D. Raes, and M. Smith. 1998. Crop evapotranspiration. Guidelines for computing crop water requirements. FAO Irr. Drainage Paper 56.
Food Agr. Organization United Nations, Rome.

Assaf, R., I. Levin, and B. Bravdo. 1975. Effect of irrigation regimes on trunk and fruit growth rates, quality and yield. J. Hort. Sci. 50:481-493.

Autio, W.R., R.A. Hayden, W.C. Micke, and G.R. Brown. 1996. Rootstock affects ripening, color, and shape of 'Starkspur Supreme Delicious' apples in the 1984 NC-140 cooperative planting. Fruit Var. J. 50(1):45-53.

Bartram, R.D., W. Bramlage, E.M. Kupferman, K.L. Olsen, M.E. Patterson, and J. Thompson. 1993. Apple maturity program handbook. U.S. Dept. Agr., Agr. Res. Serv., Tree Fruit Res. Sta., Wenatchee, WA.

Behboudian, M.H. and T.M. Mills. 1997. Deficit irrigation in deciduous orchards. Hort. Rev.) 21:105-131.

Behboudian, M.H., B.S. Mpelasoka, Z. Singh, and T.M. Mills. 2005. Quality responses of deciduous fruit to deficit irrigation, p. 33-43. In: R. Dris (ed.). Fruit: Growth, nutrition, and quality. WFL Publisher (Science \& Technology), Helsinki, Finland.

Chaplin, M.H. and A.R. Dixon. 1974. A method for analysis of plant tissue by direct reading spark emission spectroscopy. Appl. Spectrosc. 28:5-8.

Chun, I.J., E. Fallahi, W.M. Colt, B. Shafii, and R.R. Tripepi. 2001. Effects of rootstocks and microsprinkler fertigation on mineral concentrations, yield, and fruit color of 'BC-2 Fuji' apple. J. Amer. Pomol. Soc. 55:197-205.

Drake, S.R., E.L. Proebsting, M.O. Mahan, and J.B. Thompson. 1981. Influence of trickle and sprinkle irrigation on 'Golden Delicious' apple quality. J. Amer. Soc. Hort. Sci. 106:255-258.

Fallahi, E., I.J. Chun, G.H. Neilsen, and W.M. Colt. 2001a. Effects of three rootstocks on photosynthesis, leaf mineral nutrition, and vegetative growth of 'BC2 Fuji' apple trees. J. Plant Nutr. 24:827834.
Fallahi, E., W.M. Colt, and B. Fallahi. 2001 b. Optimum ranges of leaf nitrogen for yield, fruit quality, and photosynthesis in 'BC-2 Fuji'. Apple. J. Amer. Pomol. Soc. 55:68-75.

Fallahi, E., B. Fallahi, B. Shafii, and B. Morales. 2007a. Water use, tree growth, and leaf mineral nutrients of young 'Fuji' apples as influenced by different irrigation systems. Acta Hort. 721:63-70.

Fallahi, E., R. Ratnaprabha, R. Tripepi, B. Shafii, and B. Fallahi. 2007b. Tree growth, yield, fruit quality, and mineral partitioning as affected by rootstock and irrigation methods. Intl. J. Fruit Sci. 7:3-24.

Leib, B.G., H.W. Caspari, C.A. Redulla, P.K. Andrews, and J.J. Jabro. 2006. Partial root zone drying and deficit irrigation of 'Fuji' apples in a semi-arid climate. Irr. Sci. 24:85-99.

Mills, T.M., M.H. Behboudian, P.Y. Tan, and B.E. Clothier. 1994. Plant water status and fruit quality in 'Braeburn' apples. HortScience 29:1274-1278.

Naor, A., S. Naschitz, M. Peres, and Y. Gal. 2008. Responses of apple fruit size to tree water status and crop load. Tree Physiol. 28:1255-1261.

Neilsen, D., G.H. Neilsen, D. Gregory, T. Forge, and B.J. Zebarth. 2008. Drainage losses of water, $\mathrm{N}$ and $\mathrm{P}$ from microirrigation systems in a young, high density apple planting. Acta Hort. 792:483-490.

Neilsen, D., G.H. Neilsen, L. Herbert, and S. Guak. 2010. Effect of irrigation and crop load management on fruit nutrition and quality for Ambrosia/M.9 apple. Acta Hort. 868:63-72.

Neilsen, D., S. Smith, G. Frank, W. Koch, Y. Alila, W. Merritt, B. Taylor, M. Barton, J. Hall, and S. Cohen. 2006. Potential impacts of climate change on water availability for crops in the Okanagan Basin, British Columbia. Can. J. Soil Sci. 86:909-924.

Neilsen, G.H., P. Parchomchuck, and D. Neilsen. 1994. Fertigation of fruit trees: The B.C. experience, p. 191-199. In: 
A.B. Peterson and R.G. Stevens (eds.). Tree fruit nutrition. Good Fruit Grower, Yakima, WA.

O'Connell, M.G. and I. Goodwin. 2007. Responses of 'Pink Lady' apple to deficit irrigation and partial root zone drying: Physiology, growth, yield, and fruit quality. Austral. J. Agr. Res. 58:1068-1076.

Proebsting, E. 1994. Strategy development for managing drought, p. 39-50. In: K.M. Williams and T.W. Ley (eds.).
Tree fruit irrigation. Good Fruit Grower, Yakima, WA.

Talluto, G., V. Farina, G. Volpe, and R. Lo Bianco. 2008. Effects of partial root zone drying and rootstock vigour on growth and fruit quality of 'Pink Lady' apple trees in Mediterranean environments. Austral. J. Agr. Res. 59:785-794.

Washington State University. 2012. Washington State University Tree Fruit Research and Extension Center. 20 Mar. 2012. $<$ http://www.tfrec.wsu.edu>.
Yao, S., G.H. Neilsen, and D. Neilsen. 2001. Effects of water stress on growth and mineral composition of 'Gala' apple fruit. Acta Hort. 564:449-456.

Zydlik, Z. and E. Pacholak. 2001. Fertigation effects on the concentration of mineral components in the soil and leaves, and the yield and quality of fruit in two apple tree cultivars. Acta Hort. 564:457463. 